\title{
The market as lived experience \\ On the knowledge of markets in antitrust analysis
}

\section{Gustavo Onto}

\section{Resumo}

Este artigo descreve algumas reflexões, histórias e práticas analíticas de assessores e conselheiros do órgão antitruste brasileiro (CADE) a respeito dos mercados, setores, indústrias - ou seja, do mundo econômico - que eles buscam compreender e administrar. A atividade desses profissionais exige, principalmente, uma avaliação de determinadas características de mercados para que se possa estabelecer uma estratégia de investigação de alegações de práticas anti-competitivas de mercado e para que se possa julgar os casos sob responsabilidade deste tribunal antitruste. A partir de entrevistas com esses profissionais e de observação participante do trabalho analítico por eles executado, procura-se ressaltar modos de conhecer e conceber os mercados que são paralelos àqueles utilizados oficialmente e mais explicitamente pelos burocratas da autoridade antitruste. A descrição desses modos laterais de conhecer, que aqui aparecem como um conjunto de experiências vividas pessoais e familiares -, é posta em relação com as práticas etnográficas de produção de conhecimento, tendo em vista refletir sobre a importância da experiência vivida na literatura de antropologia e sociologia dos mercados. Palavras-chave: mercado; experiência vivida; para-etnografia; conhecimento; antitruste; CADE.

\section{Abstract}

This article describes some of the reported thoughts, anecdotal observations and analytic practices of advisors and commissioners working at the Brazilian antitrust body (CADE) regarding the markets, industries, sectors - i.e. the economic world - which they aim to understand and regulate. The 
activity of these professionals primarily requires an evaluation of certain market characteristics in order to establish strategies for the investigation of allegations of anti-competitive market practice and for passing judgment on administrative cases filed before the antitrust tribunal. Based on interviews with these professionals and participant observation of their analytical work, this article seeks to describe modes of knowing and conceiving markets which are parallel to the modes officially and more explicitly relied upon by antitrust bureaucrats. We present these lateral modes of knowing as a set of personal lived experiences and compare them to ethnographic practices of knowledge production, in order to reflect on the importance of lived experience in the anthropological and sociological literature on markets.

Keywords: market; lived experience; para-ethnography; knowledge; antitrust; CADE. 


\title{
The market as lived experience
}

On the knowledge of markets in antitrust analysis

\author{
Gustavo Onto
}

\section{Introduction'}

The most fundamental problem antitrust confronts is dealing with complex market information through institutions whose competence is limited.

(Hovenkamp, 2005:11)

I realized very early on that, in my fieldwork in Kabylia, I was constantly drawing on my experience of the Béarn society of my childhood, both to understand the practices that I was observing and to defend myself against the interpretations that I spontaneously formed of them or that my informants gave me. (Bourdieu, 2003:288)

On April $3^{\text {rd }}$, 2013, I accompanied the work of an advisor from the Administrative Council for Economic Defence (CADE), which is a governmental body under the auspices of the Brazilian Ministry of Justice responsible for Brazilian antitrust policy, or 'competition defence' policy as it is also known. The advisor's work on that occasion involved 'defining the relevant market' for a company takeover in the oncological treatment sector. When notified of a proposed merger, acquisition or other 'act of concentration' CADE usually needs to define the relevant market, in order to be able to evaluate the likely impact on competition. The takeover operation that had

\footnotetext{
1 I especially wish to thank Federico Neiburg, Juan Pablo Pardo-Guerra, Afrânio Garcia, Eugênia Motta, Benoît de L’Estoile, Fernando Rabossi, Laurence Fontaine, Andrés Góngora Sierra, André Dumans Guedes, Rejane Valvano, Luiz Alberto Couceiro, Rodrigo Cantu, Pedro Magalhães Batista, Isabelle Menezes, and Taylor Nelms whose comments, suggestions and questions helped make the argument of this article more precise and coherent. I also would like to thank Jonathan Francis Roberts for the detailed revision of this article in English.
} 
been reported to CADE and assigned to the advisor for analysis, involved the acquisition of one hospital by another in the municipality of Rio de Janeiro. The acquisition gave rise to a risk of market concentration that could reduce competition: it was therefore necessary, to define the market that might be affected by the takeover in order to then draw up an 'index of concentration' and decide on any action that might be necessary.

In this specific case, the question was whether 'hospitals' and 'clinics' could be considered players in the same market and, therefore, potential competitors in the provision of medical-hospital services for oncological treatment. If they were part of the same market, the acquisition would cause little alteration to the market concentration, given that the number of clinics in the region was large enough to counterbalance the market power of the new hospital. After explaining how she usually defined the market in this sector, by calculating the radial distances between clinics, the advisor, a law graduate, stated that: 'in this market, from my own experience, I know that the clinics probably don't compete with hospitals.'

Somewhat taken aback by her seemingly abrupt conclusion, I asked how she had acquired such specific information. She explained that some years previously her father had been diagnosed with cancer and that she remembered vividly that her father had not needed to go to hospital to undertake his chemotherapy sessions. This was because, she added, of a new treatment that did not even require the patient to visit a clinic every day. The treatment involved an implant placed over the chest, releasing the medication during the course of the day, making it unnecessary for the patient to leave home, she explained. This meant, she added, that 'there is, perhaps, no horizontal concentration between hospitals and clinics', since her father had not needed to visit hospital, only a clinic from time to time. Logically, therefore, 'clinics' and 'hospitals' could not be competing in the same market, since the services they provide are different.

The technicality of 'defining the relevant market' can be obscure and incomprehensible to anyone unfamiliar with the world of antitrust policy and law. The way in which the advisor established a relation between the market definition and her father's treatment exemplified the reasoning implicit in this antitrust practice, but also demonstrated an alternative way of understanding the market. During the analysis of administrative processes, the professional staff of the Brazilian antitrust body, whatever 
their academic background, frequently draw on personal or lived experiences (which may be their own personal experiences or the experience of others known to them) to help them infer particular characteristics of markets, sectors, industries or companies - i.e. the economy. These experiences lived by advisors, commissioners or technical assistants - which, I argue, can be conceived as ways of knowing or assessing the economic world are used alongside the official practices of knowledge production typical of administrative law. Lived experiences may be drawn upon either as a complement to official practices or as a way of questioning them. Turning to examples such as the one presented above, my goal here will be to describe these intuitive, experiential, 'lateral' knowledge practices (Maurer, 2005; Riles, 2011), which permeate the analysis and judgement of cases, in order to reflect on the interpretative tools regulators use. I conclude that market experiences are relevant elements in comprehending market expertise and market constructions.

The Brazilian antitrust agency ${ }^{2}$, CADE, where I undertook the research leading to this article ${ }^{3}$, acts in accordance with principles and methods commonly used by antitrust agencies world-wide. This autonomous legal body (autarquia ${ }^{4}$ ) which operates under the auspices of the Ministry of Justice, is responsible for enforcing antitrust law and policy in Brazil. Antitrust can be defined as a 'set of policies and laws designed to ensure that competition in the markets is not reduced in a way that diminishes economic well-being' (Motta, 2004:30). Antitrust bodies across the world base their decisions on the assumption that competition ${ }^{5}$ in markets is

2 Strictly speaking, CADE is not an 'agency' under the specific legislation governing regulatory agencies - I use the term here as a more convenient way referring to 'autonomous administrative bodies' (see footnote 4 below).

3 I conducted the ethnographic research over a two-year period at the offices of the Brazilian antitrust agency, in Brasilia, as part of my doctoral thesis in Social Anthropology at the National Museum (Federal University of Rio de Janeiro). The research involved observation of the knowledge practices needed for the investigative proceedings relating to competition law and included, for one semester, my active participation as a technical analyst for CADE's General Superintendence.

4 According to Meirelles (2010:380): 'Autarquias are autonomous administrative bodies, established by specific laws, legally defined as a domestic government bodies, with their own assets and specific state powers [...] these bodies are self-managing, in accordance with laws issued by the entity responsible for creating them.'

5 The concept of competition is perhaps the most ambiguous concept in antitrust analysis, despite being a central notion in said field. Economic theory is not unanimous on the definition of competition for the purposes of antitrust policy and, consequently, competition is defined in a variety of forms for different analytic purposes. See Davies (2009) on the potential differences in the concepts of competition applied by antitrust agencies in the United States and the United Kingdom. 
economically advantageous for consumers and for the national economy as a whole. Competition is presumed to enable consumers to purchase products at lower prices and to make companies more innovative and productive (Forgioni, 2013). Antitrust policy, which is present throughout most of the industrialized world in a remarkably similar manner, is an ever-increasingly important feature of the Brazilian government's economic policy. Starting in the 1990s, new competition laws have been introduced seeking to bolster anti-inflationary measures (Onto, 2009). Policymakers consider antitrust policy to be an essential feature of an open modern economy, effectively guaranteeing one of Brazil's constitutional principles: free competition (Salgado, 1995).

The Brazilian antitrust body is responsible for the filing, investigation, prosecution $^{6}$, and judgment of administrative proceedings relating to competition law. During an investigation, the agency generally seeks to gather legal-economic evidence for use in the administrative proceedings. The investigation commonly includes the analysis of documents and interviewing or consulting relevant individuals, companies, political authorities and entities in the public or private sector. The agency may apply for search and seizure warrants in order to inspect the headquarters and other premises of the companies under investigation, and seize objects, papers, computers, etc. All these measures are aimed at the gathering of the evidence needed to determine the veracity of allegations of potentially anti-competitive behaviour or to determine whether a merger might lead to a possible economic harm for consumers or competitors.

These administrative procedures or practices are designed to gather information on the specific characteristics of the markets, companies and consumers involved or affected in the case. The many factors analysed include, for example, information on the respective revenues of the relevant market players, the start-up costs that a new player must incur in order to

\footnotetext{
6 Instrução [investigation] refers to the set of legal formalities and level of information needed for a case to reach a state where it can be judged. According to the legal expert Hely Meirelles (2010:742): 'investigation is the fact-finding phase, involving the production of admissible evidence by the plaintiff in punitive processes, or additions to the initial evidence in control and licensing processes: this evidence ranges from testimonies from the parties involved, examination of witnesses, personal inspections, technical reports, to the gathering of relevant documents. In punitive proceedings, responsibility for the investigative measures rests with the prosecuting authority or commission, while in the other kinds of processes it lies with the parties who have an interest in the decision concerning the object of the case, through direct presentation of evidence or official request for its production through regulatory procedures.'
} 
enter a market, the sector's production and innovation characteristics, how product prices are formed, the relevant brand or trademark values and the location of production and distribution units. This information is needed for a conclusion as to whether or not a merger between firms might result in a competition problem or whether a particular business practice amounts for example to a cartel, being a 'violation of the economic order' under the national competition law.

Although I focus on lateral knowledge practices in this article in no way do I seek to diminish the importance of the legal and institutional methods antitrust authorities rely upon in their work. Lateral knowledge practices are no substitute for the need to abide by formal data collection procedures, but may serve as an alternative or complement in the interpretation of real world situations not entirely detached from the experience of advisors, analysts, commissioners and interns. In fact, as we shall see, these professionals bring personal and other familiar experiences to the centre of antitrust analysis in a continual dialogue with the procedures, reasoning, doctrine and theories which characterize what the sociological and anthropological literature on markets refers to as economic or legal expertise (Mitchell, 2002; Riles, 2010). According to Holmes (2009:410), these kinds of lateral practices are common among experts who manage or regulate the economy, given that 'these actors are fully aware of the unstable nature of the economic phenomena they are charged with managing as well as the limitations of their analytical tools designed to measure, if not predict, its performance.'7

In a series of articles, Douglas Holmes and George Marcus (2005, 2006, 2008) developed the notion of 'para-ethnography' in reference to a new ethnographic possibility for the exploration of fields of expertise in which a scientific or technocratic ethos prevails. This concept refers to forms of knowledge production that are similar to ethnography and which are used by informants to complement mathematical and statistical theory in their attempt to understand the economy. In the case they studied, Holmes and Marcus give as an example of para-ethnographic procedures the calls and conversations frequently initiated by the President of the US Federal Reserve, Alan Greenspan, in order to 'sense' the economy. It was more through the knowledge obtained from these 'parallel' conversations, than the official

$7 \quad$ See also Miyazaki and Riles (2005). 
indicators produced by the bank that the President of the Fed sought to comprehend the market's expectations and the various potential economic scenarios. Para-ethnography therefore constitutes a reflexive and critical genre of understanding, a 'variety of traditional interpretive concerns with "native points of view"' (Holmes and Marcus, 2005:247).

Para-ethnographic knowledge practices - which draw on such forms of knowledge as intuition, memory, anecdote or experience - can also be described as ways of providing an explanation, a more intimate or localized context, for a phenomenon which is usually explained by abstract models (Reichman, 2011). These forms of 'illicit knowledge,' as Holmes and Marcus define them, appear to translate the abstract into the concrete, and point to the need to introduce contextual elements that can bring a more detailed account to overly generic models - in the form of what we could call 'ethnographic sketches'. However, as Daniel Reichman suggests, para-ethnographic elements may also involve a decontextualization and generalization of phenomena understood as local and particular. Whether as generalizations (decontextualizations) or through particularizations (contextualizations), the observation of para-ethnographic practices in fields of economic expertise permits the ethnographer to approach the intuitive and experiential aspects that permeate analytic reconstructions of the economic relations by drawing on comparisons, analogies or information coming from experiences of other times and places. These knowledge practices aim to reconstitute, interpret and define economic phenomena that cannot be simply measured and calculated (Holmes, 2009).

Reflecting on the above studies, I seek to describe in this article some of the interpretive practices adopted by CADE advisors and commissioners during their analytic work. Given that these lateral practices are not formally documented and are not therefore made textually explicit as part of the decision making processes, either in the formal rulings of the commissioners or in the technical reports produced by the analysts and advisors, these ways of knowing are not easily visible other than by close ethnographic research. In this paper I draw on interviews with CADE employees and my observations of dialogues between employees during their work on cases of suspected anti-competitive activity. I have focused in particular on the lived experience that they brought to their work and upon which they relied as a formative part of their processes of constructing lines of analysis 
and judgement. When CADE employees work on defining markets or on ascertaining whether a competition problem exists, they need to produce not only knowledge of markets, but also (or indeed as an alternative) they may need to bring to light knowledge produced from or within markets.

Firstly, therefore, I argue that lived experiences must be regarded as a central element of socio-anthropological conceptualizations of the market, even when these experiences are described by agents who are only 'laterally' connected to the markets such as, for example, state regulators (Elyachar, 2010; Riles, 2011). This emphasis on the experience of regulators also seeks to reflect on the way in which the literature deals with market expertise. Instead of defining such expertise merely as a 'specialized body of knowledge', paraethnographic practices require us to consider more fluid, ambiguous and contextual forms of expertise, as Annelise Riles (2010) proposes. Economic regulation bases itself both on the personal and professional experiences of regulators as well as on models and techniques set out in textbooks and guidelines on economic analysis.

Secondly, I argue that the fact that these lateral modes of market knowledge may be considered analogous to the ethnographic practices of anthropologists, and that they play a key role in the analysis and judgement of many cases dealt with by the antitrust body, requires us to reflect on contemporary forms of market regulation and how best to study them.

This article is divided into three parts. In the next section I briefly describe CADE's activity, based on the agency's official documents, highlighting the way in which an administrative proceedings are investigated and then tried by the Council. This overview is necessary in order to demonstrate how lived experience can be perceived as a lateral knowledge practice. In the following section I describe situations arising during the investigative phase of two different sets of proceedings in which the production of market knowledge drew, in different forms, on knowledge constructed in personal situations, which backgrounded the official administrative investigation practices. Finally I conclude with a few remarks on market construction, expertise, and regulation.

\section{Antitrust analysis on paper}

In Brazil, the antitrust body (CADE) performs the functions assigned to 
it under the Competition $\mathrm{Law}^{8}$, its mission being 'to strive to ensure free competition in the market'. The antitrust agency investigates two main types of administrative proceedings ${ }^{9}$ or cases: (i) 'acts of concentration', that is, mergers, acquisitions, incorporations, joint ventures, and other forms of cooperation, whether temporary or permanent, between large companies and that may jeopardize 'free competition', (ii) 'anti-competitive practices', the most well-known being cartels. ${ }^{10}$ In the former case (acts of concentration), CADE carries out an investigation in order to decide whether or not to authorize the act of concentration in question. In the latter case, it investigates suspected anti-competitive practices in order to decide whether or not to impose sanctions. In relation to acts of concentration the analysis is undertaken with the aim of preventing the potential harm that a concentration may cause to market competition in the future, while in the case of suspected anti-competitive practices the investigation is retrospective, seeking to determine whether a particular individual practice or one coordinated between two or more companies, in the relatively recent past, caused any harm to competition.

In organizational terms CADE is made up of the Administrative Tribunal for Economic Defence (Tribunal Administrativo de Defesa Econômica), the General Superintendence (Superintendência-Geral) and the Economic Studies Department (Departamento de Estudos Econômicos). The Administrative Tribunal is composed of a President and six Commissioners ${ }^{11}$ and is responsible for judging the administrative proceedings and for ratifying settlement agreements between the agency and the companies involved in anti-competitive practices or acts of concentration. The General

8 The new Competition Law 12.529, introduced on November $30^{\text {th }}$ 2011, in force on May $30^{\text {th }} 2012$, replacing the previous Law 8.884 of 1994, altered the institutional structure of the so-called 'Brazilian Antitrust System', transferring the functions of the Secretariat of Economic Law of the Ministry of Justice to the General Superintendence of CADE and including the need for pre-merger notification to the antitrust agency.

9 'The Public Administration, in order to record its acts, control the conduct of its agents and resolve disputes involving those under its administration, makes use of diverse procedures, collectively denominated an administrative proceeding' (Meirelles, 2010:734).

10 A wide variety of anti-competitive practices exist, such as, for instance, exclusive dealing, concerted refusal to deal/sell, price fixing, price discrimination, cartels, predatory pricing and tied selling. These practices may be unilateral, when the action of a single company is involved, or they may be coordinated. Investigation of these practices may begin with a report/accusation made by a company or on the basis of market studies carried out by CADE itself.

11 Under the new legislation, the Commissioners and President are appointed by the President of the Republic following approval by the Federal Senate. They have a four-year non-renewable mandate. Both the CADE President and the Commissioners must have significant knowledge of economics or law. 
Superintendence (SG) is headed by a General Superintendent and two Vice-Superintendents, and is responsible, amongst other things, for commencement of ex-oficio proceedings and the investigation of all proceedings, referring them to the Administrative Tribunal to be judged, whenever necessary. The Economic Studies Department (DEE) produces studies and economic reports to assist the analyses of the SG and the Tribunal.

The analysis of 'acts of concentration', on which I focus in this article, follows the filing of a petition by companies requesting approval for the act of (market) concentration, or 'operation' as these acts are called. Under the new Competition Law, this request is obligatory and the failure to present the operation to CADE in time may lead to the imposition of heavy fines on the companies. ${ }^{12}$ This means that the companies cannot combine their operations administratively or legally without CADE issuing a final report of approval. The initial petition, drafted by legal representatives of the parties, is accompanied by detailed information on the companies taking part in the operation and the markets in which they participate. CADE's employees use this information to begin their analysis.

Under the former Competition Law (8.884/94), companies had to send notifications of their acts of concentration to the Secretariat for Economic Monitoring (SEAE) of the Ministry of Finance, which carried out the investigation of the process and sent a 'technical report' to CADE for judgement by the plenary. At the Plenary Council, if the Reporting Commissioner deemed it necessary, a complementary investigation could be undertaken to obtain additional information on the operation. Under the new legal system, the SG is responsible for the analysis of the acts of concentration and, in many cases, for making a final decision as to whether or not such acts may be authorized. In cases which the SG considers to be complex ${ }^{13}$, SG staff will draft a report and submit the issue to the Tribunal.

12 In relation to acts of concentration, Article 88 of the law states: 'The following are to be submitted to CADE by the parties involved in the operation of acts of economic concentration in which, cumulatively: I - at least one of the groups involved in the transaction has registered, in the last balance sheet, annual gross sales or total turnover in the country, in the year preceding the transaction, equivalent or superior to four hundred million reais (R\$ 400,00o,000.00) [approximately 168 million dollars]; and II - at least one other group involved in the transaction has registered, in the last balance sheet, gross annual sales or total turnover in the country, in the year preceding the transaction, equivalent to or greater than thirty million reais $(\mathrm{R} \$ 30,000,000.00)$ [approximately 13 million dollars].'

13 The classification of a case as 'complex' tends to be related to a higher likelihood of the operation causing a 'competition problem' in the market under analysis. As a result the Tribunal often deals with the potentially 
In the more straightforward cases which the SG handles alone, the SG report constitutes the agency's final decision.

Several members of CADE staff (advisors or analysts) may be involved in the analysis of the facts and issues pertaining to an act of concentration. Their analysis is based on assumptions taken from various economic theories, particularly those relating to industrial organization and microeconomics ${ }^{14}$ which enable the formulation of hypotheses on the behaviour of companies, competitors and consumers in a scenario of increased economic concentration. Financial, accounting, corporate and contractual analyses may also be used in a case report. The analysis evaluates the impact a particular concentration of companies is likely to have on market competition in a specific geographical location.

The Guia para Análise Econômica de Atos de Concentração Horizontal (Horizontal Merger Guidelines) published by Brazilian antitrust agencies in 2001 suggest a five-stage process for the analysis of acts of concentrations ${ }^{15}$. The first of these stages is the definition of the 'relevant market', that is, the delimitation of the market affected by the operation. The precise definition of a market (the definition of the competing companies, products or services offered and the geographic locality affected by the operation) is almost always necessary in order to establish where the impact of the concentration will be felt. The second stage is the estimation of 'market power', that is, the relative market share held by one or more companies within a relevant market. Estimation of these market shares enables analysts to construct indices of market concentration (such as the $\mathrm{C}_{4}$ index set out below), providing a quantitative prediction of future market scenarios. The third stage involves the analysis of the market's present and future 'entry barriers', that is, the actual and potential conditions for new competitors to enter the market. The fourth stage involves an evaluation of the potential gains and losses for consumers and competitors arising from a merger within

more harmful cases, which demand more time for assessment by the antitrust agency.

14 The contemporary economic antitrust analysis of market concentrations draws on theories and methods from both the so-called Harvard School of Industrial Organization and the Chicago School. No single approach prevails over the other in the Brazilian agency, albeit individual Commissioners might be more inclined towards a particular theoretical approach. In general, structural analyses (Harvard) are combined with analyses of the operation's economic efficiency (Chicago) or more recent considerations related to transaction costs (Hovenkamp, 2010).

15 Horizontal mergers occur when two companies competing in the same market merge or join together. A vertical merger is one in which a firm or company joins a supplier or distributor. 
the market, including assessment of the 'economic efficiencies' that can be generated by the operation. This means that analysts look to measure the potential gains and cost reductions for the merging companies as a result of reorganization of production or the capacity to innovate. Finally a costbenefit analysis is undertaken, looking at the trade-off between the gains and losses of the concentration, combining all the information collected in the investigation and assessing whether the operation poses any risk to competition in the analysed market.

All these analytical questions suggest that the more information the agency possesses on the companies, competitors and consumers in a market, the better-placed it will be to estimate the impact on competition caused by a concentration. The chart below, produced by the SEAE and SDE (the defunct Secretariat of Economic Law), illustrates the various stages of the procedure:

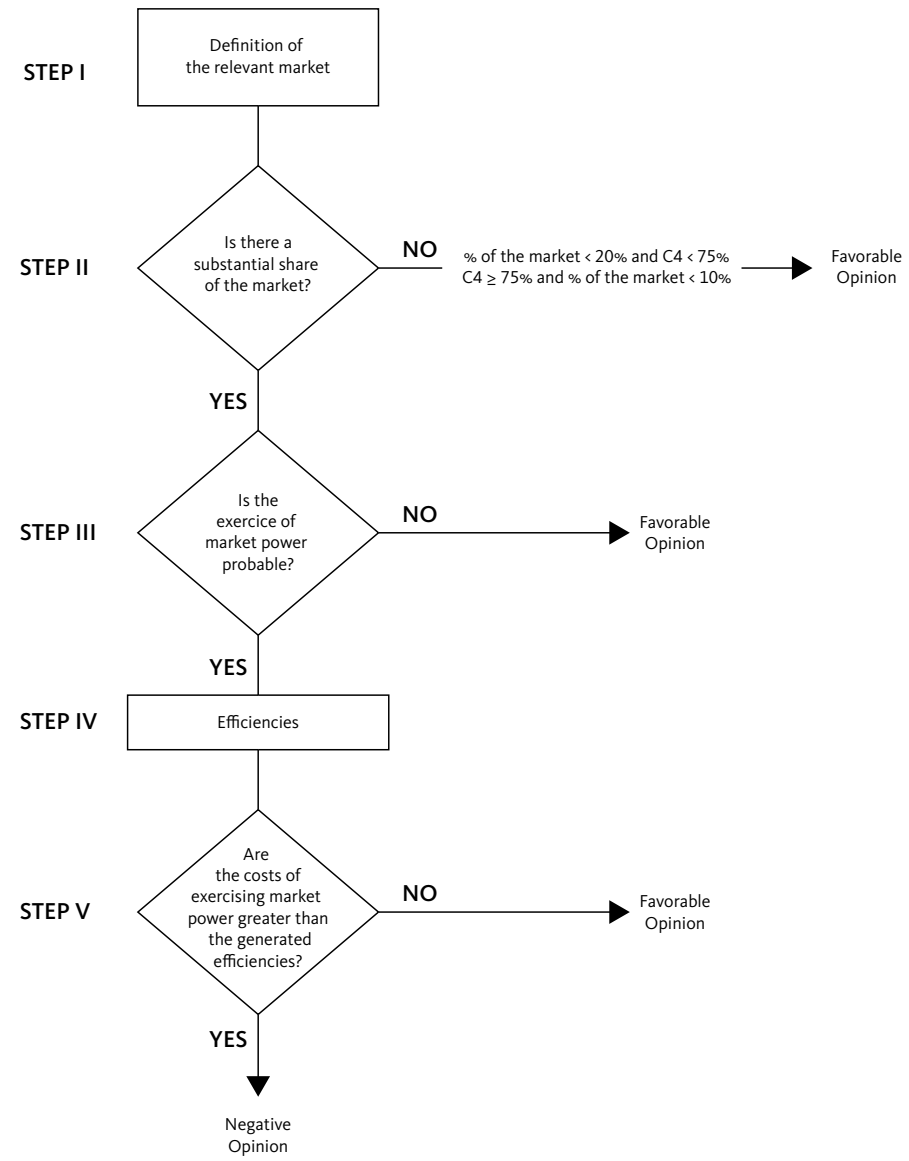

Steps in the Economic Analysis of Horizontal Mergers (SEAE/SDE, 2001) 
The analytic model presented above, which is based on the U.S. Federal Trade Commission merger guidelines ${ }^{16}$, presents an outline or framework for the analytical activity of bureaucrats inside the antitrust agency, by illustrating, for the purposes of accountability, what they do (or should do) when they analyse a case. The guidelines also enable a series of agents outside those agencies to undertake their functions in line with the activities of the antitrust body ${ }^{17}$. These external agents include the 'business community' and the 'antitrust practitioners', that is the lawyers and economic consultants who need to 'speak the same language' as the antitrust body, which requires them to be capable of evaluating market concentrations in a similar way (Onto, 2009) ${ }^{18}$. That said, it is worth noting that the techniques and procedures described in the guidelines, whilst frequently adopted, are not necessarily required in every merger investigation. The extent of their use depends on the needs and specific characteristics of the case analysed.

While the merger guidelines point to the economic reasoning underlying the analysis of the cases by the Council, another set of documents resolutions, directives, flowcharts, legal texts - describe how this analysis is (or should be) undertaken in practice - i.e. the formal and legal procedures for carrying out the analysis. ${ }^{19}$ Generally (and formally) speaking, CADE's

16 The U.S. merger guidelines are widely relied upon as a reference for other countries' merger guidelines, given that the Federal Trade Commission (FTC) and the Department of Justice (DoJ) are considered by antitrust experts to be among the most efficient and technically sophisticated antitrust agencies in the world. As one bureaucrat at the Brazilian antitrust body said to me: 'we are living in an environment in which the wealthier economies dictate antitrust "best practices"... so, consequently, as you can see, Brazilian analytic practices and procedures are now starting to become part of world's best practices and are being praised by the OECD and ICN [International Competition Network]'

17 A report on merger guidelines produced by different antitrust agencies worldwide contains the following description: 'Guidelines set out how authorities intend to apply the laws and regulations in their respective jurisdictions to the cases that come before them. Guidelines are important not only for deliberation on those cases but also for obtaining consistent results in law enforcement. They might influence which merger proposals are made in the first place and they are a mechanism for the authorities to be transparent about the operation of the policy, and to be held to account for its proper implementation.' (ICN, 2004)

18 In the case of the U.S. and other jurisdictions where investigative proceedings and trials are conducted by separate institutions, the guidelines serve the purpose of educating judges in antitrust economic reasoning. Courts that try antitrust cases are expected to be able to follow as closely as possible the modes of reasoning described by antitrust agency's guidelines, although this does not always happen, in practice (see Hovenkamp, 2005).

19 Comparing the merger guidelines with the other documents produced by the agency allows us to explore one of the possible modalities of the relation between law and economics within antitrust agencies. These agency documents describe a relation in which economics (and 'the economy') comprises the content of the analysis and law comprises the form in which the analysis must be performed. According to one economist, also a CADE employee: 'In antitrust, the law adopts an economic criterion of legality. Moreover, while the legitimizing principle - the promotion of competition and efficiency - is economic, the means are legal and institutional. 
investigative and analytical activity is no different to that performed at other state administrative or regulatory bodies in accordance with procedures common to Brazilian Administrative Law. These procedures include the sending of official communications to the companies involved in acts of concentration and to their competitors, together with questionnaires and spreadsheets to be completed, the inspection of production facilities, meetings with company lawyers or directors, research in newspapers and magazines or on the internet, telephone conversations, and other activities.

However many of these investigative/analytic practices are not written into the agency's internal resolutions and directives, much less into the Competition Law or the Federal Constitution. Likewise many of these practices also pass unmentioned in the most important textbooks on the area of Competition Law or Antitrust Economics, whether foreign (Hovenkamp, 2005; Motta, 2004) or Brazilian (Forgioni, 2010). It could be said that the official documents and text books in the area do not seek to describe these practices, since they would be as numerous or diverse as the number of professionals and processes that pass daily through CADE. As anthropologists of the State would argue, making these practices explicit is not the objective of such documents. Timothy Mitchell (2002), for example, suggests that para-ethnographic practices cannot be legitimized as official since they would eliminate the very formality that the State strives to maintain. It is these knowledge practices, which are frequently employed but not officially made explicit and are kept in the background, that we call lateral, or para-ethnographic.

To avoid any misunderstanding of the central argument of this paper, it is worth stressing that jurists do not deem the use of personal experiences to be improper, illegitimate or illegal. From a legal point of view, para-ethnographic practices are neither strange nor indeed unusual, but, rather, they are a common interpretive exercise in judicial proceedings. It is not my intention in this paper to discredit legal rationality by arguing that the process of case judgement is subjective and 'ideological'. What I seek is to reflect, from the

\footnotetext{
This is because antitrust policy is exercised by the application and interpretation of what the law characterizes, in accordance with these objectives, as anti-competitive and abusive (and therefore unlawful) practices, or as circumstances that increase the probability of harm to competition - making these circumstances undesirable and liable to control. Consequently to the extent that the promotion of a competitive environment requires state intervention, it ends up attributing a significant role to law, albeit wrapped up in an "eminently economic function", since it is designed to obtain efficiency through its norms' (Alves, 2010:61).
} 
point of view of legal advisors and commissioners, on the production of knowledge concerning markets, their agents and their transformations.

My doctoral research at the Brazilian antitrust agency began in March 2012, but it was only from September of the same year that I was able to follow the work of three advisors and two interns at the office of one of the agency's commissioners. For six months I accompanied, as an observer, the work carried out at this office. Apart from the commissioner, who had a $\mathrm{PhD}$ in Economics, and the head of the office (a psychologist by training), the other employees were all Law graduates or undergraduates. Furthermore, the advisors in question, who in this case had only been working at the agency for a few months, did not have any specific training in antitrust policy and legislation. They were learning, almost at the same time as myself, how to carry out a competition analysis.

When I mentioned my interest, as an ethnographer, in understanding how analyses and judgements were carried out at the antitrust agency, the advisors and commissioners would immediately point to textbooks, decisions, guidelines and the internal regulations as a broad description of the work that they did. As they well knew and warned me, however, these various forms of guidelines merely introduced me to a set of practices, theories and questions that might assist in the difficult task of understanding how a concentration of companies was to be analysed. As David Mosse states (2007), all the variety and contingencies which relationships, interests, events, expectations and experiences produce in the practice of public policies are reduced to a minimum when one observes the description provided in official documents.

While the discourse contained in these documents necessarily 'suppresses the relational', 'refuses significance to the event, the individual and compromise [...] in favour of the rule, instrumental ideas, [and] professional models' (Mosse, 2007:12-13), the day-to-day analytical practices performed by the employees seemed to bring to the fore personal and professional relationships, making the activity of administering markets less bound to a certain pre-established rationality of how the economic world works. Similarly, but certainly not identically, to the modes of knowledge construction typical of ethnographic practice, the CADE investigative analysis of markets and their agents also sought to contextualize (or decontextualize) certain economic relations in order to be able to 
comprehend the potential effects of a market concentration. Many of these knowledge practices manifested as an extension of the antitrust analysis to the sphere of lived experience, as exemplified in the next section.

\section{A personal experience}

The work of investigating processes at CADE never seems to leave the computer screens. Advisors, commissioners, technical assistants and interns spend the whole day writing texts or filling out spreadsheets in the commissioner's offices and atother coordination offices. Discussion between advisors and commissioners concerning the particularities of cases is limited due to the short amount of time available and the large number of cases to be analysed. Even so, it is notable that in constructing their understanding of cases during these brief parallel conversations, whether at occasional office meetings or during summarized explanations of cases, staff members refer to considerations and assessments of characteristics of the market under investigation that do not come from information contained in documents sent by the companies or from the agency's case law. Rather, they draw on lived experiences and other subjectivities. It was as the result of a question an advisor at CADE asked me, in relation to my own personal experience, that I began to consider these lateral knowledge resources as an ethnographically significant object.

In the office where I was conducting my research, the advisors and commissioners would meet fortnightly for a case conference on the issues they were currently handling. The case files were placed on the meeting table and opened one-by-one in order to discuss the possible ways of proceeding with the analysis. One of the advisors would pick up a file and read the first pages out loud so that the others might know what the case involved and the possible 'competition issue' it raised. In general the questions that then arose related to the type of additional material (information or data) that needed to be requested from the applicant company ${ }^{20}$ (or from its competitors) in order to clarify any important points and assist the commissioner, with the advisor's help, to draft this or her written decision.

20 As mentioned earlier, the examples cited in this work all relate to acts of concentration. For this reason the companies are referred to as 'applicants' since they applied for administrative authorization to carry out an operation (merger, acquisition...), rather than being termed 'representatives', or 'represented parties', as the companies are called in investigations of violations of the economic order, such as cartels, for example. 
In the period in which the ethnographic research was undertaken, CADE was undergoing a period of transition. The new Competition Law had come into force but there were still a number of pending acts of concentration which had arisen whilst the former law was in force and were therefore governed by the former statutory provisions. Such applications were called the 'stock. ${ }^{21}$ The cases concerned were distributed among the commissioners and the entire investigative process was undertaken within their offices. It was by accompanying some of these investigations that I began to familiarize myself with the Council's processes of analysing and judging acts of concentration. ${ }^{22}$

At a meeting of the commissioner with two advisors in October 2012, the group's attentions were focused on a spreadsheet, which covered an entire page of a petition, ${ }^{23}$ bearing the names and location of a series of university centres. The location of the centres was identified by the complete address, most of them located in the Greater São Paulo region. The spreadsheet had been sent by the applicants in order to enumerate the complete set of university centres that would form part of a single economic group, if the act were to be approved by CADE. This is a mandatory requirement in applications of this nature ${ }^{24}$ : in the case at hand, two companies that controlled separate universities and faculties were merging to form a single economic group.

After the spreadsheet had been passed around to everyone present, one of the advisors asked me: 'So, Gustavo, you lived in São Paulo, what's the distance from Avenida Paulista to this place here in São Bernardo do Campo?' He pointed to two different university locations presented by the company. 'Oh, and from Avenida Vergueiro to Avenida Paulista?’ I replied that I could not say what the exact distance was, but that it probably took

21 The elimination of this 'stock' was a priority for the Presidency of the Council following the promulgation of the new Competition Law. Judging all these processes would mean, in practical terms, a shift to a new legal framework, considered by government officials as more efficient and effective than the previous one for the task of enforcing competition.

22 It would be impossible to describe the entire process of analysis of a single case, from start to end, from an ethnographic viewpoint, due to the impossibility of accompanying a case as it moves through the different commissioner's offices, coordination offices and departments within the antitrust agency. My aim is merely to indicate the existence of lateral knowledge practices that, at any moment of analysis, may be utilized by advisors, commissioners and interns. 
more than thirty minutes, without heavy traffic, to travel from Avenida Paulista to São Bernardo. The advisor then asked: 'But you, if you lived in the Paulista region, would you commute to São Bernardo to study?' I said that I probably would not, as there were several universities closer to Avenida Paulista that were probably very similar to the one in São Bernardo and that I could not imagine anyone commuting in such circumstances.

The advisor's questions reflected his attempt to comprehend how the information set out in the table could lead to a conclusion on the existence or absence of a 'competition problem'. The first question, which referred to the distances between university centres, sought to identify the concentration of units in a spatial, geographic dimension. In other words, were the units presented by the applicant concentrated in a particular region? If so, what was the scale of this supposed region? Since at that point in my field research I already understood why the advisor was interested in the distance between the units, I replied with another item of information: the estimated time required for travelling between the two.

My reply provided something that for me, based on my own personal experience, was easier to calculate. I do not remember ever covering this specific trajectory by car, but I had already commuted enough by car in the city of São Paulo to be able to provide a reasonable estimate of the time taken between two locations. In my reply to the first question, the variables of distance and time travelled indicated characteristics that could be translated into an economic vocabulary as characteristics of the 'supply side', indicating the availability of services in a particular region. The question asked of me concerned my experience as a resident of São Paulo, someone familiar with the city's geography, its distances and above all the road traffic conditions.

The first question could provide information on something that the documents did not contain (yet). Undoubtedly these questions could be answered in replies to official communications sent to the applicant company and its competitors. In fact, the applicant company was in due course formally requested to present evidence of the distance between its units. The distance and time involved could also have been calculated at CADE using Google Maps, as is done normally. However, the answer to those questions, at that moment of office meeting, enabled a quicker estimate of the characteristics of the market concerned and facilitated the formulation of other relevant questions and other potential lines of enquiry. 
The question subsequently asked by the advisor took into account different variables, which could result in a more precise estimate of the geographic area he wanted to define. The question 'if you lived in the Paulista [Avenue] region, would you commute to São Bernardo to study?' placed me in the situation of a potential consumer of 'educational services' who lived near Avenida Paulista and would have a decision to make were he to go to university. What would I (or someone like me) do in this situation, the advisor wondered? Looking to complement the information obtained from the first question, what the advisor wanted to know, in economic terms, was the 'demand side' of this market, that is, how a consumer of educational services and resident in São Paulo's central region would behave. In reply I added another piece of information relating to 'supply' in this specific region: I said that the universities were potential competitors in the region of Avenida Paulista. Hence it was neither necessary nor reasonable to suppose that a consumer would commute from the Paulista region to São Bernardo (a suburban area of the city).

Based on these two responses, the advisor could infer, or at least suspect, that the market he was looking to understand would not include all the university centres in question. If a consumer would not commute from Avenida Paulista to São Bernardo to study, as I suggested, the two universities in question were probably located in different 'geographic markets': they did not therefore compete for students. Furthermore if many other university centres existed in São Paulo's central region, then perhaps the competition between the entire range of universities in the area (and not just the two universities that were proposing to merger) should be the focus of the analysis. As explained in the previous section, antitrust analysis must start by defining a geographic area accompanied by the definition of a product or service that may be affected by the business concentration. Using the information I provided, the geographic area of this market could at least be estimated with greater precision, remaining fairly close to the Paulista region.

My personal experience enabled the advisor to understand, to some extent, the functioning of the educational services market in São Paulo. More specifically, it offered an insight into the decision-making rationale of a typical consumer of these services in the city. By being able to infer characteristics of consumers and the travel times involved, as well as being able to ascertain, albeit not conclusively, the presence and extent 
of competition, the advisor could elaborate further questions for the merging companies and for their potential competitors in the market. The 'competition dynamic' in this market began to acquire a more solid (and ethnographically informed) character that enabled an evaluation of whether the proposed merger would cause any harm to the 'economic order'.

\section{A familiar market}

Some of the cases referred to CADE end up generating a huge amount of work for those responsible for their analysis. Some cases in particular call for very detailed examination of the issues. Two notable examples are (i) cases in which there is a perceived likelihood of CADE rejecting an application for a merger (circumstances in which CADE analysts must provide clear and thoroughly researched analyses upon which the Tribunal can rely as grounds for the rejection) and (ii) administrative proceedings in which there is a possibility of the Tribunal imposing a fine or other sanctions for anti-competitive practices (e.g. in the case of cartels). The rejection of an operation or the imposition of a penalty for anti-competitive practice are discussed extensively at the meetings of commissioners and are, later on, subject to intense challenge from the lawyers representing the parties. The advisor and in particular the Reporting Commissioner on the decision come under considerable pressure that demands, simultaneously, significant technical rigour in the analysis and considerable flexibility in interacting with their peers and representatives of the companies involved. One of the cases I accompanied at a Commissioner's office also demonstrated to me the importance that knowledge from and within markets has in the evaluation of the effects of an act of concentration.

The case involved the purchase of a hospital by the shareholders of another hospital in a town I shall call Pequi, located in the interior of Minas Gerais State ${ }^{25}$. The town only had two hospitals and so the acquisition would result in the total control of the provision of hospital care by one company, Santé. The applicants' lawyers claimed that the acquisition was necessary for 'logistical reasons' and would not harm competition since the hospital being

25 Because of the confidential nature of the information on the proceeding, the names of the location and the company involved in this operation have all been changed. 
purchased was on the verge of bankruptcy. Failure to purchase the hospital would, they said, generate more unemployment and reduce the supply of medical services since the hospital would close ${ }^{26}$. Furthermore the demand for medical-hospital services in the town could not economically sustain two hospitals competing for clients. In other words, despite creating a single economic group, which would control the town's only two hospitals, the acquisition would benefit the market of hospital services in this location, or at least prevent its decline.

As well as stressing the potential bankruptcy of the hospital they were attempting to buy, the applicants alleged that control of the two hospitals would generate economic efficiencies that would compensate for the existence of an inevitable monopoly in the town ${ }^{27}$. The two hospitals could jointly purchase medical supplies and combine their organizational departments, thereby saving resources, which would lead to lower variable costs and, therefore, lower prices for patients. Santé was the owner of both the purchasing hospital and of the health insurance plan used by the majority of the town's population. This, according to its lawyers, would allow the company to improve its performance by adjusting the hospital's and the health plan's objectives, resulting in 'allocative efficiencies' that would benefit both hospitals and the consumers.

In daily conversations with the Reporting Commissioner, I witnessed his difficulty in accepting the arguments presented by the applicant companies. In his view, the likelihood of the purchased hospital going bankrupt was small. If there were a real risk of the target company becoming bankrupt, it would be reasonable to suppose, for example, that other companies would also have made bids for the hospital, but this had not happened. On the contrary, only the controlling group of the town's largest hospital had shown an interest in the purchase. Moreover the profitability and liquidity indicators from the target hospital, taken from its balance sheet and financial statements, did not point to any major risk of insolvency. It would

26 This argument is known as the theory of the failing firm: 'The failing firm defence (FFD) has arisen infrequently in merger cases but is expected to be used more frequently in the current economic climate. The FFD exists in most OECD jurisdictions and exempts an otherwise anticompetitive merger from challenge under the competition laws if the target company is in such poor financial condition that its only other option would be to exit the relevant market' (OECD, 2009).

27 I use the term monopoly although in fact there was a third (very small) hospital in the town, which, due to its diminutive size, 'was incapable of rivalling the other two' (Felipe, advisor, personal conversation). 
be difficult for CADE, with this data, to agree to a concentration that would place in the hands of one company the control of over ninety per cent of hospital services in the town of Pequi.

Later on during the investigation of the process, an advisor named Felipe, who was assisting the Commissioner in this case, visited the hospitals in Pequi (at the request of the Commissioner), in order to obtain 'a concrete notion of the case'. Visits to companies take place in a few cases only, usually at the request of Commissioners or at the invitation of applicants. According to the advisor, in the case in question 'as it happened, the Pequi hospital was indeed extremely run down, in a much worse state than the other one [...] I recall that the X-ray room was under the staircase and had mildew, it was a very precarious situation...' During his visit the owners of the other hospital had assured him that they intended to modernize the purchased hospital, bringing it up to the standards of the facility they already controlled. Faced with this range of information, it was no simple matter for the Commissioner to reach a final judgment, particularly after Pequi's mayor visited CADE to say that the takeover would benefit the region's health sector.

Despite the mayor's visit and the findings of the advisor, the Commissioner ended up rejecting the operation, blocking the purchase of the hospital. When I asked him, after the ruling why he had come to that conclusion, he gave an explanation that had not been set out (or even alluded to) in the written decision:

'The situation was as follows. My father-in-lawwas an auditor for Santé [health insurers] and my father set up a dermatological clinic for my sister there in [the town of] Uberaba ${ }^{28}$, there in a small building she [my sister] owned, on one floor. It so happened that my sister did not have Santé there ${ }^{29}$. She had Amil [another health insurance provider], among others, but not Santé. And there you had a problem of ninety percent having [the health insurance of] Santé. The population in Uberaba, right? Almost all the doctors were accredited by Santé. So then I remember the struggle of my sister, my mother. And my sister trying to speak to my father-in-law: "look into it for me, Ineed to be accredited. I'm already accredited with Santé in Belo Horizonte [capital of the State of Minas Gerais], but I need to be accredited by Santé in Uberaba". Why? Because she wasn't able to get herself accredited. My father-in-law told her: "It's no use,

28 Uberaba is a relatively small city in the State of Minas Gerais, not far from the town I have called 'Pequi'.

This means that she was not authorized by the Santé health insurance to treat their clients. 
there are already so many [accredited doctors] there, Santé won't add any more." And they didn't, she was unable to get accredited by Santé in Uberaba. She couldn't manage it. Right? So she had to chargefor appointments. Except that in a town like Uberaba, with a very poor population, if you charge 100 reais, which is really cheap for a doctor, people just won't pay it, they will look for a dermatologist covered by Santé's insurance. What happened? She stayed open a year and half, two years. And closed. She simply closed the clinic and went back to Belo Horizonte. Why? Because it wasn't worth keeping the clinic open. She closed the clinic because she was unable to keep it going.'

The account transcribed above contains another example of Santés activities in a small town. Although the issue of concentration in Pequi (the issue that was before $\mathrm{CADE}$ ) was quite different to what had taken place in Uberaba (a town in which the Commissioner had once lived), the company involved was the same. In the case under investigation, Santé sought to takeover a hospital that, according to Santé lawyers, was not economically self-sustaining. In the events that affected the commissioner's sister, what seemed to be worrying (from a competition standpoint) was the power Santé had over the provision of medical services, that is, over the doctors themselves. Despite her father-in-law working for Santé, The Commissioner's sister had been unable to obtain the accreditation needed for her to treat patients covered by the company's health insurance. The Commissioner's explanation continued:

'When I took the Santé case, this thing did not come to my mind immediately. This thing came to my mind following numerous discussions with the plenary [meetings with the other commissioners] and with the lawyers, who were saying that people would be made unemployed. "Look, if it weren't for this merger, if it breaks down, you'll see people unemployed". So right then, this came into my mind. I said: "but what about the doctors who will be made unemployed? There are several who will become unemployed. Whose unemployment are you talking about?" Then the story of my sister came into my head. I had also received an email from a doctor in Pequi, saying: "I'm going to have to leave Pequi, I'll have to work in Ouro Preto, because I have nowhere to work. I'm not with Santé, I was with Regional [another health insurance provider]." That was when I said to everyone in the plenary discussion: "Listen everyone, what unemployment are you talking about? Because look, if you allow 90\% of the health insurance coverage in two hospitals, the doctors will be unable to work [...] You can require the applicants to sign a Term of Commitment if you like, 
but it won't work." So they suggested a fifteen-year TCD ${ }^{30}$ and I said: "Do what you like, only you're generating inefficiency and there will be people who won't be able to enter this market. Right?" That was the connection.'

The Commissioner said that it was only during the discussions in which the argument on unemployment arose that the story of his sister 'came into his head'. The email from a doctor from Pequi made him realize the connection between his own family experience and the case under his analysis. This, for the commissioner at least, added another dimension to the issue. That the near absence of competition between hospitals would result in fewer options for consumers was just one of the possible effects of this merger. He became aware of another market: the employment market of the Pequi doctors. This market would also be affected by the merger, and in a way with which the commissioner was very familiar since he had witnessed the professional difficulties faced by his sister.

'Unemployment might affect the X-ray technician, the guy who cleans the hospital, but here you are making unemployed someone specialized, a doctor. The doctors are left without options; you close the market for them. I have investigated other closures which were like that: it was the same case as my sister. More than that, you are not closing only [the market] for the doctor, you are closing the clinics, because look, what happened to my sister was that they closed the market of a dermatological clinic, it had to close [...] The haemodialysis clinic did not survive, the oncology clinic did not survive, it is all integrated, it all depends on doctors referring [the patients]. So when you close the oncology clinic you lose the cleaners working in the oncology clinic [...] so it is necessary to ponder both things. What type of unemployment are you talking about? We have to make a choice then. A trade-off between who is going to be made unemployed. The truth is this: it's not possible for everyone to keep theirjobs. But it is obvious that if you leave some competition the probability of someone staying employed is higher than without competition. So I used the experience of my sister, you see?'

As well as the job market for self-employed doctors, there was also the risk of negative impacts on the clinics that depended on the functioning of the hospital. The predominance of just one health insurance provider in the town would make competition between clinics non-existent. The hospitals

30 A TCD (Termo de Compromisso de Desempenho) is a Term of Commitment signed by the applicants and CADE in order to guarantee a certain conduct by the companies, insuring that market competition conditions are not transformed after the act of concentration. 
(both controlled by the same health insurance company) would refer patients to accredited clinics only, 'closing the market' to the others. Furthermore, in his view, the unemployment of doctors was more serious than for other staff (cleaners, technicians...). A specialized professional like a doctor would be unable to find work elsewhere in the town. The Reporting Commissioner became convinced, through his personal experience, that the promised economic efficiencies would not compensate for the monopoly in Pequi. For this reason he preferred to vote for the rejection of the acquisition, deciding to keep at least one competitive 'rival' in the market instead of permitting the formation of a monopoly of medical-hospital services.

\section{Concluding Remarks}

To recover the knowledge which comes from perceiving structural relationships between events, we might have to seek the counterpart of our systematizing endeavours in people's artefacts and performances, in the images they strive to convey, and thereby in how they present the effects of social action to themselves. (Strathern 1990:28)

This article has sought to show the ways in which employees of Brazil's antitrust agency make use of lived experiences (their own, or experiences known to them) in order to understand economic relations in given markets and the effects that acts of concentration can have on these relations. Each of the examples given illustrates knowledge practices that constitute merely one moment in the process of analysing an antitrust case. The variables influencing the analysis and judgment are practically infinite and it would be impracticable to enumerate them all or even classify the most significant according to their importance in the final decision. The described moments - which constitute what we can call para-ethnographic knowledge practices, following Holmes and Marcus (2005) - may vary in terms of their degree of influence on the decision-making process. What seems to be more important, from the point of view of economic anthropology, is not the pervasive influence these practices may have on the decisions and judgments, or even the fact of their being used instead of formal analytic procedures, but, rather, the way in which these lived experiences become tools in antitrust analysis for interpreting how market competition operates. 
In a recent ethnography of the Japanese financial market, Hirokazu Miyazaki (2013) explains how the concept of arbitrage and its principle of eliminating differences was used by traders as a general interpretive mechanism. As an exchange strategy, arbitrage involved the buying and selling of shares with the expectation that the market would change in the near future, allowing the trader to obtain profits from the alteration in asset prices. According to Miyazaki, traders did not apply this principle to their work alone, as a method of profit making, but extended it to their personal dreams, their future business plans and their analyses of the Japanese economy. The ethnographer writes: 'In these extensions of arbitrage as an interpretive device, Sekai [bank] traders alternately became both subjects and objects of arbitrage' (Miyazaki, 2013:33).

In a different, albeit comparable environment, the para-ethnographic practices of antitrust policy, which construct associations that give meaning to the case under investigation, show how market competition is both an object to be managed and, simultaneously, part of the life of the agency's employees. These employees may be consumers, residents at specific locations or simply people who are familiar with the markets in question, being subjects who have experienced market relations similar or identical to those that the agency is required to interpret ${ }^{31}$. Regulators try to deal with external, imponderable market realities by putting themselves, whenever possible, in the position of decision-making market participants (consumers, CEO's, shopkeepers...). These lateral knowledge practices place the employees in the position of active subjects of the markets, experiencing the inner workings of such markets, ${ }^{32}$ in a manner which is similar to the activity of the ethnographer who puts him or herself in the place of the objects studied in order to objectify his or her relations with them (Bourdieu, 2003).

31 Not all markets are capable of being easily understood through personal experience so, in many cases, this form of knowledge is not relied upon. Markets such as 'laminated steel', 'piloting' or 'fertilizers', for instance, generally do not fall within the scope of the life experience of professionals such as economists and lawyers.

32 The employee's previous professional experience or interest generates a social distribution of expertise in relation to markets within the antitrust agency. Many of the agency's advisors or analysts end up becoming specialists in a given sector. It is common to hear, for example, that some advisor has more background knowledge of a particular market or sector (due to professional, life experience or even personal interest), which results in him being called upon to give his opinion about cases falling within his field of knowledge. Companies can also be known para-ethnographically, since their practices may be part of the experiences of several antitrust employees. Discussions of brands, products and services are common, along with how they are marketed and produced, or how certain companies work and what past history and reputation they have. 
The question then arises, how can the dimension of lived experience and, sometimes, highly individual experience, contribute to the study of market performations, which has been developed in the anthropological and sociological literature on markets (Callon, 2007; MacKenzie, 2009)? How does subjectivizing practices help us to understand better the market constructions, which are part of antitrust analytical work? The anthropological literature on markets has focused attentively on the socio-physical construction of markets, the role of economic knowledge and the material conditions needed for the construction of economic arrangements and devices, defining markets as socio-technical assemblages (Callon and Muniesa, 2005; Callon, Millo and Muniesa, 2007; Çaliskan and Callon, 2010). Markets are understood in these studies as associations between material and discursive, human and nonhuman elements. If these marketization studies can be defined as 'the entirety of efforts aimed at describing, analysing and making intelligible the shape, constitution and dynamics of a market socio-technical arrangement' (Çaliskan and Callon, 2010:3), lived experiences might appear to be merely an additional effort in the description of this assemblage, considering that antitrust analytical work is to a very great degree a study of 'marketization'.

What I suggest, however, is that lived experiences are not simply complementary to technocratic modes of understanding the economy, but are sometimes alternatives that bring to the fore other market attachments that are difficult to grasp through traditional technocratic modes of knowledge. Therefore, as in the case of other market participants studied in the literature (Miyazaki, 2003), antitrust regulators can use para-ethnographic practices not just to enhance or bolster the analysis of competition - an almost surreptitious form of knowing that completes the judgment of a case. If we restrict the study of markets to an ever increasing enumeration of entities that compose, assemble and form them, that is, to 'market devices' (Callon, Millo and Muniesa, 2007), we overlook the possible alternatives market regulators and participants use to make sense of economic relations. I argue that, in particular cases, antitrust regulators use lived experiences as an alternative way of understanding markets and do so to such an extent that the traditional forms and techniques of analysis become merely legal requirements which they use pragmatically, as a way of convincing their peers, companies and interested parties of the soundness of the conclusions arrived at. By doing this, they in fact bring to the fore a new market that can only be grasped as experience. 
Various forms of interpretive practices in market exchange have been the object of reflection in the literature of economic sociology and anthropology, particularly in the social studies of finance (Zaloom, 2003; Preda, 2007). However, the practices described in these studies mostly feature as a residue of the technical analysis with which market participants engage. Additionally, these related experiences do not extend much beyond the organizations and professional trajectories which are closely tied in to the quotidian work of traders. However, studies involving market regulators and other market builders not considered central to market exchange have demonstrated that market expertise, in the sense of a technical esoteric form of knowledge, is not the only relevant point of interest (Riles, 2010; 2011; Holmes, 2014). Experiences, intuitions, anecdotes or the capacity to 'objectivate the subject of objectivation' (Bourdieu, 2003) ) $^{33}$ are as important, and sometimes even more important, as an interpretive tool for understanding and intervening in markets. These embodied knowledge practices (Elyachar, 2010) enact markets as 'spaces of sensibilities'.

Concerning the world of experts on the economy, Holmes and Marcus (2005:248) affirm that their object of study 'is not the interior lives of experts as an elite as such, but rather to understand their frame, which we assimilate by collaboration and complicity, for a project of tracking the global' (to envisage the economy as a whole), where the ethnographer must be 'engaged with its dynamics from their orienting point of view.' This paper's focus on lateral knowledge practices has precisely the same aim of reconstructing this global, intuitive, native vision of the economy, required for understanding the effects, or perhaps even affects, of market concentrations. My objective is to show that the study of antitrust and other economic policies can benefit from making use of this perspective, which sees regulation 'as a kind of ethnographic account of the past with an eye toward the future' (Maurer, 2012:313).

Translated from the Portuguese by David Rodgers and revised by Jonathan Francis Roberts

Received November 11th., 2013. Approved April $4^{\text {th }}$., 2014.

33 Pierre Bourdieu's explanation of his approach to reflexivity can be used as a native description of an antitrust regulator's own practices: to consider 'the effects of knowledge of my objectivizing posture, that is, the transformation undergone by the experience of the social world (...) when one ceases to 'live' it simply and instead takes it as object' (Bourdieu, 2003:289). 


\section{References cited}

ALVES, Camila. 2010. Métodos quantitativos na avaliação dos efeitos de fusões e aquisições: uma análise econômica e jurídico-institucional. Tese de Doutorado, Insituto de Economia, UFRJ.

BOURDIEU, Pierre. 2003. "Participant objectivation". Journal of the Royal Anthropological Institute, 9 (2): 281-294, February.

BRASIL. Lei $\mathrm{n}^{\circ}$ 12.529, de 30 de novembro de 2011, Estrutura o Sistema Brasileiro de Defesa da Concorrência; dispõe sobre a prevenção e repressão às infrações contra a ordem econômica; altera a Lei no 8.137, de 27 de dezembro de 1990, o Decreto-Lei $\mathrm{n}^{\circ}$ 3.689, de 3 de outubro de 1941 Código de Processo Penal, e a Lei $n^{\circ} 7.347$, de 24 de julho de 1985; revoga dispositivos da Lei $\mathrm{n}^{\circ} 8.884$, de 11 de junho de 1994, e a Lei $\mathrm{n}^{\circ} 9.781$, de 19 de janeiro de 1999; e dá outras providências.

ÇALISKAN, Koray \& CALLON, Michel. 2010. "Economization, part 2: a research programme for the study of markets". Economy and Society, 39(1): 1-32.

CALLON, Michel. 2007. "What does it mean to say that economics is performative?”. In: D. MacKenzie, , F. Muniesa \& L. Siu (eds.), Do economists make markets? On the performativity of economics. Princeton University Press. pp. 311-357.

CALLON, Michel \& MUNIESA, Fabian. 2005. "Economic markets as calculative collective devices.” Organization Studies, 26(8): 1229-1250.

CALLON, Michel, MILLO, Yuval, MUNIESA, Fabian. (eds.) 2007. Market devices. Malden: Blackwell Publishing.

DAVIES, William. 2009. Competition and competitiveness: a cultural political economy. Thesis submitted for the degree of $\mathrm{PhD}$ in Sociology. London, Goldsmiths, University of London.

ELYACHAR, Julia. 2012. "Before (and after) neoliberalism: tacit knowledge, secrets of the trade, and the public sector in Egypt". Cultural Anthropology, 27(1): 76-96.

FORGIONI, Paula. 2013. Os fundamentos do antitruste. $6^{\text {a }}$ edição. São Paulo: Editora Revista dos Tribunais.

HOLMES, Douglas. 2009. "Economy of words”. Cultural Anthropology, 24(3): 381-419.

HOLMES, Douglas. 2014. Economy of words: communicative imperatives in central banks. Chicago: The University of Chicago Press. 
HOLMES, Douglas \& MARCUS, George. 2005. "Cultures of expertise and the management of globalization: toward the re-functioning of ethnography”. In: A. Ong and S. J. Collier (eds.), Global assemblages. Oxford: Blackwell. pp. 235-252.

HOLMES, Douglas. 2006. "Fast capitalism: para-ethnography and the rise of the symbolic analyst”. In: Melissa S. Fisher and Greg Downey (eds.), Frontiers of capital: ethnographic reflections on the new economy. Durham, NC: Duke University Press. pp. 33-57.

HOLMES, Douglas. 2008. "Collaboration today and the re-imagination of the classic scene of fieldwork encounter". Collaborative Anthropologies, 1: 81-101.

HOVENKAMP, Herbert. 2005. The antitrust enterprise: principle and execution. Cambridge: Harvard University Press.

HOVENKAMP, Herbert. 2010. "Harvard, Chicago and transaction cost economics in antitrust analysis”. Antitrust Bulletin, 55. pp.613. Available at SSRN: http:|/ssrn.com/abstract=1592476. Access on August 15th, 2013.

INTERNATIONAL COMPETITION NETWORK (ICN). 2004. "Report for the third ICN annual conference in Seoul. April.” Available at ICN: http:// www.internationalcompetitionnetwork.org/uploads/library/doc563.pdf

MACKENZIE, Donald. 2009. Material markets: how economic agents are constructed. Oxford: Oxford University Press.

MAURER, Bill. 2005. Mutual life, limited: Islamic banking, alternative currencies, lateral reason. Princeton: Princeton University Press.

MAURER, Bill. 2012. "Regulation as retrospective ethnography: mobile money and the arts of cash". Banking and Finance Law Review, 27(2): 299-313.

MEIRELLES, Hely Lopes. 2010 [199o]. Direito administrativo brasileiro. 37 a Edição. São Paulo: Malheiros Editores.

MITCHELL, Timothy. 2002. Rule of experts: Egypt, techno-politics, modernity. Berkeley: University of California Press.

MIYAZAKI, Hirokazu. 2003. “The temporalities of the market”.American Anthropologist, 105(2): 255-265.

MIYAZAKI, Hirokazu. 2013. Arbitraging Japan: dreams of capitalism at the end of finance. Berkeley: University of California Press.

MIYAZAKI, Hirokazu. \& RILES, A. 2005. “Failure as an endpoint”. In: A. Ong and S. J. Collier (eds.), Global assemblages. Oxford: Blackwell. pp. 320-331.

MOSSE, David. 2007. "Notes on the ethnography of expertise and professionals in international development". Ethnografeast III: ethnography 
and the public sphere. Lisbon, June 20-23. Available at: http://ceas.iscte.pt/ ethnografeast/papers/david_mosse.pdf

MOTTA, Massimo. 2004. Competition policy: theory and practice. Cambridge: Cambridge University Press.

OECD. 2009. Roundtable on failing firm defense. Directorate for financial and enterprise affairs. Competition Committee. Available at: http://www.oecd. org/daf/competition/mergers/45810821.pdf. Access on August 5th, 2012.

ONTO, Gustavo. 2009. Da irrelevância do mercado ao mercado relevante: economistas, teoria econômica e política antitruste no Brasil. Dissertação de Mestrado em Administração Pública e Governo, FGV-EAESP, São Paulo.

PREDA, Alex. 2007. "Where do analysts come from? The case of financial chartism”. In: M. Callon, Y. Millo, F. Muniesa (eds.), Market devices. Malden: Blackwell Publishing. pp. 40-64.

REICHMAN, Daniel. 2011. "Migration and paraethnography in Honduras”. American Ethnologist, 38(3): 548-558,

RILES, Annelise. 2010. “Collateral expertise: legal knowledge in the global financial markets". Current Anthropology, 51(6): 795-818.

RILES, Annelise. 2011. Collateral knowledge: legal reasoning in the global financial markets. Chicago: The University of Chicago Press.

SALGADO, Lucia Helena. 1995. "Política de concorrência: tendências recentes e o estado da arte no Brasil”. Texto para Discussão no. 385, IPEA, Brasil. Mimeo.

SEAE e SDE. Secretaria de Acompanhamento Econômico do Ministério da Fazenda e Secretaria de Direito Econômico do Ministério da Justiça. Portaria Conjunta n. 50, de 10 de agosto de 2001. http://www.cade.gov.br/ internacional/Horizontal_Merger_Guidelines.pdf

STRATHERN, Marilyn. 1990."Artifacts of history: events and the interpretation of images". In: J. Siikala (ed.), Culture and history in the Pacific. Helsinki: Finnish Anthropological Society. pp. 25-44.

ZALLOM, Caitlin. 2003. "Ambiguous numbers: trading technologies and Interpretation in financial markets". American Ethnologist, 30(2):1-15. 